\title{
Féltermészetes agrártájak ökoszisztéma-szolgáltatásai a gazdálkodók szemszögéből
}

\author{
Balázs Bálint ${ }^{1,2}$, Kelemen Eszter ${ }^{1}$, Pataki György ${ }^{1,3}$ és Bela \\ Györgyi ${ }^{1,2}$ \\ ${ }^{1}$ Environmental Social Science Research Group (ESSRG), \\ 1024 Budapest, Rómer Flóris u. 38. \\ ${ }^{2}$ Szent István Egyetem, Természetvédelmi és Tájgazdálkodási Intézet, 2100 Gödöllő, \\ Páter Károly u. 1. \\ ${ }^{3}$ Budapesti Corvinus Egyetem, \\ 1093 Budapest, Fövám tér 8. \\ e-mail: balazs.balint@essrg.hu
}

\begin{abstract}
Összefoglaló: Az agrártájak féltermészetes élőhelyei pótolhatatlanul fontos ökoszisztéma-szolgáltatásokat nyújtanak, mint például a beporzás, a kártevők és a talajerózió szabályozása, a széndioxid megkötés vagy a tájesztétika. Ezen élőhelyek ökoszisztéma-szolgáltatásaira azonban eddig csak kevés kutatás irányult Európában, s azok is meglehetősen féloldalasok. A QUESSA FP7-es kutatásban interjús és fókuszcsoportos kutatással vizsgáltuk, hogy a féltermészetes élőhelyek ökoszisztémaszolgáltatásait mennyire ismerik, hogyan értékelik a tájban élő gazdálkodók. A gazdálkodók részvételén alapuló nem pénzbeli ökoszisztéma-szolgáltatás értékelési módszereinkkel nehezen számszerüsíthető társadalmi hasznokat, kulturális értékeket mutattuk ki, és nem találtunk áthidalhatatlan különbséget a gazdálkodói és a tudományos ökoszisztéma-szolgáltatás elgondolásokban. A közös mérlegelés pedig tovább segített az ökoszisztéma-szolgáltatás fogalom gazdagításában, a féltermészetes élőhelyek mezőgazdasági használaton túlmutató hasznainak megismerésében.
\end{abstract}

Kulcsszavak: féltermészetes élőhely, ökoszisztéma-szolgáltatás, QUESSA FP7, agrárökoszisztéma, kvalitatív kutatás, nem pénzbeli értékelés

$$
\text { „A gazdálkodásnál nincsen zöldebb munkahely” }
$$

(de Schutter \& Petrini, 2017)

A gazdálkodókat a jövőben arra kell bíztatni, hogy újraértelemzzék munkájukat: "Fotoszintézis menedzser vagyok és ökoszisztéma szolgáltatások biztositásával foglalko-

zom".

(Sandhu \& Wratten, 2013. 10. o.) 


\section{Bevezetés}

Az ökoszisztéma-szolgáltatások fogalma határfogalom a közpolitika és a tudomány, a természet- és a társadalomtudományok mezsgyéjén (Kovács et al. 2011). Az ökoszisztéma-szolgáltatások tudományos fogalma a kézzelfogható és kézzel nem fogható javakra (termékekre és szolgáltatásokra) vonatkozik, amelyek az ökológiai rendszerek természetes vagy ember által befolyásolt müködése során keletkeznek, és hozzájárulnak a társadalom, s benne az egyén jóllétének növeléséhez (Kelemen 2011). Bár a definíció kiforratlan, és pontos használatáról sincs konszenzus, az ökoszisztéma-szolgáltatás értékelések közös célja a természet magától értetődőnek gondolt, sokrétủ értékeinek láthatóvá tétele (Nahlik et al. 2012, Lele et al. 2013).

Az ökoszisztéma szolgáltatások értékelésére használt módszerekkel kapcsolatban számos dilemmát tárgyal a szakirodalom (magyarul bỏvebben ld. Kelemen 2011, Kelemen \& Pataki 2014). Kifogásolható, hogy a pénzbeli értékeléseknél a megállapított érték nem áll szoros összefüggésben a legfőbb érintettek preferenciáival, akiket a leginkább érintene az ökoszisztéma-szolgáltatásokkal kapcsolatos döntés. Különösen jellemző ez a piaccal nem rendelkező kulturális és szabályozó szolgáltatásokra, amelyeknek gyakran önmagában vett értéket vagy társadalmikulturális értéket is tulajdonítanak az érintettek (Haines-Young \& Potschin 2010). Felmerül, hogy az egyéni értékelések aggregálásával előállított pénzbeli érték teljesen fiktív (Wilson \& Howarth, 2002), vagy az ökoszisztéma-szolgáltatások különféle aspektusainak tulajdonított értékek nem összeegyeztethetők és ezért nem is aggregálhatók (Martínez-Alier, 2002). Az sem világos, hogy piaci alapon hogyan biztosítható az ökoszisztéma-szolgáltatások optimális elosztása (Baveye et al. 2013, 2016). E kritikai észrevételekre is épít az IPBES értékmegközelítése és javasolt módszertana, amely az ökoszisztéma szolgáltatásokhoz kapcsolódó értékek sokféleségét hangsúlyozza, és az integrált - a változatos értékeket egyaránt figyelembe vevő - értékelésre buzdít (Pascual et al. 2017). A szakirodalomban több példát találhatunk arra, hogy az értékelés során nem pusztán az ökoszisztéma-szolgáltatások gazdasági értékét, hanem a tágabb jóllétre gyakorolt hatását - például a jövő generációkra vonatkozó egészségügyi, társadalmi, esztétikai vonatkozásokat is figyelembe veszik (O’Hara 1996, idézi Kumar \& Kumar 2008, p. 814). A nem pénzbeli értékelési eljárások, különösen a párbeszédre építő részvételi módszerek, a természetvédelem, a tudomány és helyi közösségek számára lehetővé teszik, hogy közösen alakítsák a természetről vallott nézeteiket, és az értéktulajdonítást beemeljék az adott helyi kontextusba (Santos-Martín et al. 2017).

Az öko-agrár-élelmiszer komplex rendszer, vagyis a mezögazdaság és az ökoszisztéma-szolgáltatások közötti kapcsolatok átfogó értékelésére alakult csoport, 
a TEEBAgriFood a kölcsönhatások társadalmi, környezeti, gazdasági és egészségügyi vonatkozásait tárja fel (TEEB 2015). A társadalom által élvezett ökoszisztéma-szolgáltatásokat ugyanis egyetlen szektor sem befolyásolja erőteljesebben - materiális/fizikai értelemben és szakpolitikai struktúráján keresztül - , mint az agrárium.

Az agroökoszisztémák a tényleges gazdálkodási gyakorlatoktól függően csökkenthetik vagy növelhetik az ökoszisztéma-szolgáltatások választékát és minőségét (Swinton et al. 2007, De Groot et al. 2010, Lescourret et al. 2015, KovácsHostyánszki et al. 2017). E tekintetben az argárium világszerte ellentmondásos kihívással áll szemben: a növekvő globális populáció élelmiszerellátását biztosító terméshozam növelését a mezőgazdálkodási rendszerek környezetre gyakorolt káros hatásainak csökkentése mellett kell elérniük. Az ökoszisztéma-szolgáltatás keretrendszerben ez azt jelenti, hogy a mezőgazdasági gyakorlatok számos esetben a támogató, szabályozó és kulturális ökoszisztéma-szolgáltatások rovására növelik az élelmezési célú ellátó szolgáltatásokat. Ezenkívül a mezőgazdasági termelök ösztönzői a rövid távú piaci árutermelést segítik a közösség számára előnyös ökoszisztéma-szolgáltatások rovására. Következésképpen a támogató és szabályozó (és bizonyos mértékig a kulturális) ökoszisztéma-szolgáltatások egy komplex társadalmi csapda, az „ökoszisztéma-szolgáltatások tragédiája” miatt hanyatlanak, ami az ökoszisztéma-szolgáltatások mennyiségének és minőségének romlását, és az ember által nem dominált élőhelyekre való visszaszorulását eredményezi (Lant et al. 2008). Ennek környezeti, közegészségügyi és társadalmi költségei (negatív externális hatásai) nem jelennek meg az agrár-termékek árában, azokat az agrárszektor áthárítja más szektorokra és társadalmi csoportokra.

Az ökoszisztéma-szolgáltatások és az agrár-élelmiszer rendszerek kapcsolatának vizsgálata mindezek miatt elkerülhetetlen. Az egyik legégetőbb szakpolitikai dilemma, hogy lehetséges-e az agráriumot összhangba hozni a szabályozó szolgáltatások értékének megőrzésével, ökológiailag fenntartható és társadalmilag igazságos kínálatával (Pataki 2014). Az ökoszisztéma-szolgáltatás perspektíva segítheti a mezőgazdasági gazdálkodási gyakorlatokat, hogy növeljék az agroökoszisztémák fenntarthatóságát, és csökkentsék az intenzív mezőgazdaságból származó környezeti ártalmakat (Stallman 2011). Stallman (2011) szerint három fő elemzési irány adódik: az agrár-ökoszisztémákból származó szolgáltatások, az agrár-ökoszisztémák számára nyújtott szolgáltatások, valamint az agrártevékenység hatására megváltozó ökoszisztéma-szolgáltatások kihatása más ökoszisztéma-szolgáltatásokra. A természetes ökoszisztémák szolgáltatásaira hagyatkozó ökoszisztémák nélkülözhetetlenek az emberi jóléthez és más ökoszisztéma szolgáltatások és káros szolgáltatások (disservices, DSs) egész sorának nyújtásához. Az agroökoszisztémákat a szolgáltatásnyújtó ökoszisztémák elkülönült típusának 
tekintik, amelyek világszerte óriási változatosságot mutatnak (Zhang et al. 2007, illetve 1. függelék az online függelékben $[\mathrm{OF}])$.

Az élősövények, füves-virágos táblaszegélyek, legelők, fasorok, vagyis az agrártájak féltermészetes élőhelyei rendkívül jelentősek, mert egy sokk-hatásokkal szemben védtelen, kevéssé diverz (az összfogyasztás háromnegyedét 12 növényfaj és 5 állatfaj nyújtja), és ezek miatt sérülékeny élelmiszer ellátási rendszer számára biztosítják a létfontosságú ökoszisztéma-szolgáltatásokat (FAO 2016). E felismerés az EU Közös Agrárpolitikájának legújabb vitáiban is megjelenik, amennyiben már a mezőgazdasági támogatás helyett is egyre inkább komplex élelmezéspolitikáról van szó (IPES 2017). Miközben az extenzív hasznosítású agrárterületeken viszonylag nagy számban készültek ökoszisztéma-szolgáltatás értékelések, az intenzív hasznosítású agrárterületeket szegélyező féltermészetes élőhelyekre jóval kevesebb vizsgálat irányult, $\mathrm{s}$ azok is nagy egyenetlenséget mutatnak (Holland et al. 2016). Holland és munkatársai (2014) szerint a legtöbb vizsgálat a leggazdagabb agrárterületekre vonatkozik: elsősorban német, francia, spanyol, svéd és brit esettanulmányok jellemzők. Ugyanakkor ritka a több ország agrártájainak ökoszisztéma-szolgáltatásait összehasonlító kutatás (ld. pl. Kelemen et al. 2013). A vizsgálatok fókusza döntően a talajmegmunkálás, a növényvédőszer használat, a legeltetés intenzitása, a vetőmag használat és a takarónövények alkalmazása. Az agrárökoszisztémák számos ökoszisztéma-szolgáltatása közül szinte kizárólag a szabályozó szolgáltatások kapnak hangsúlyt, különösen a növényvédelem és a beporzás. További ellentmondás, hogy a kutatások a szántóföldi növényekre, elsősorban gabona és napraforgó területekre irányulnak, míg éppen a növényvédelem és a beporzás szempontjából sokkal fontosabb gyümölcs- és zöldségkultúrákra alig. Kevés figyelem irányul a sövények, táblaszegélyek, erdö- és gyepsávok szerepére - például a károsítók (kártevők, gyommagkészlet) gyérítésében (holott a természetes szabályozó mechanizmusok egyikeként ez prioritást kap az integrált növényvédelemben és a zöldítési programban is). Számos területen tudáshiány jellemző: pl. az eróziószabályozás, vízszabályozás, széndioxid megkötés témáiban (Holland et al. 2014).

Európa területének több mint felén a gazdálkodók a legfontosabb ökoszisztéma-kezelök; gazdálkodási gyakorlataik közvetlen hatást gyakorolnak az ökoszisztéma-szolgáltatások áramlására; a táj ismerete, a változások megfigyelése révén pedig kulcsfontosságú információt tudnak nyújtani az ökoszisztéma-szolgáltatások komplex összefüggéseiröl is (Sutherland et al. 2014). Termelékenységük függ az agrárterületek és szegélyeik által nyújtott jótékony és káros ökoszisztéma-szolgáltatásoktól, a tevékenységük által befolyásolt ökoszisztéma-szolgáltatások azonban az érintettek szélesebb körének jóllétét is befolyásolják, például az agrártáj nyújtotta kulturális szolgáltatások fenntartása, vagy egyes szabályozó 
szolgáltatások (pl. a talajerózió elleni természetes védekezés) aláásása révén (1. ábra Zhang et al. 2007 nyomán).

Zhang és munkatársai (2007) a gazdálkodók érdekeltségét vizsgálták az ökoszisztéma-szolgáltatás-kímélő gazdálkodásban. Az üzemi szinten jelentkező hasznok a termelők számára közvetlen ösztönzőt jelentenek, míg a nagyobb léptékủ (táji, regionális, globális) hasznok valószínübben halmozódnak fel más érintetteknél, ideértve más mezőgazdasági termelőket is, az erőforrást biztosító mezőgazdasági termelőn kívül. (A főbb szereplőket és a szolgáltatásnyújtás léptékeit összegző táblázatot az online függelék [OF] 1. függelékében közöljük.) Az ökoszisztémaszolgáltatás-kímélő mezőgazdálkodási gyakorlatot tájegységi léptékben lehet legjobban ösztönözni (Goldman et al. 2007). Stallman (2011) háromféle ökoszisztéma-kímélő gazdálkodást ösztönző tényezőt azonosított. Az ökoszisztéma-szolgáltatási körzetek jogintézményének a legmagasabbak a tranzakciós költségei, valamint a tájegység relatív homogenitását is igényli. A mezőgazdasági ter-

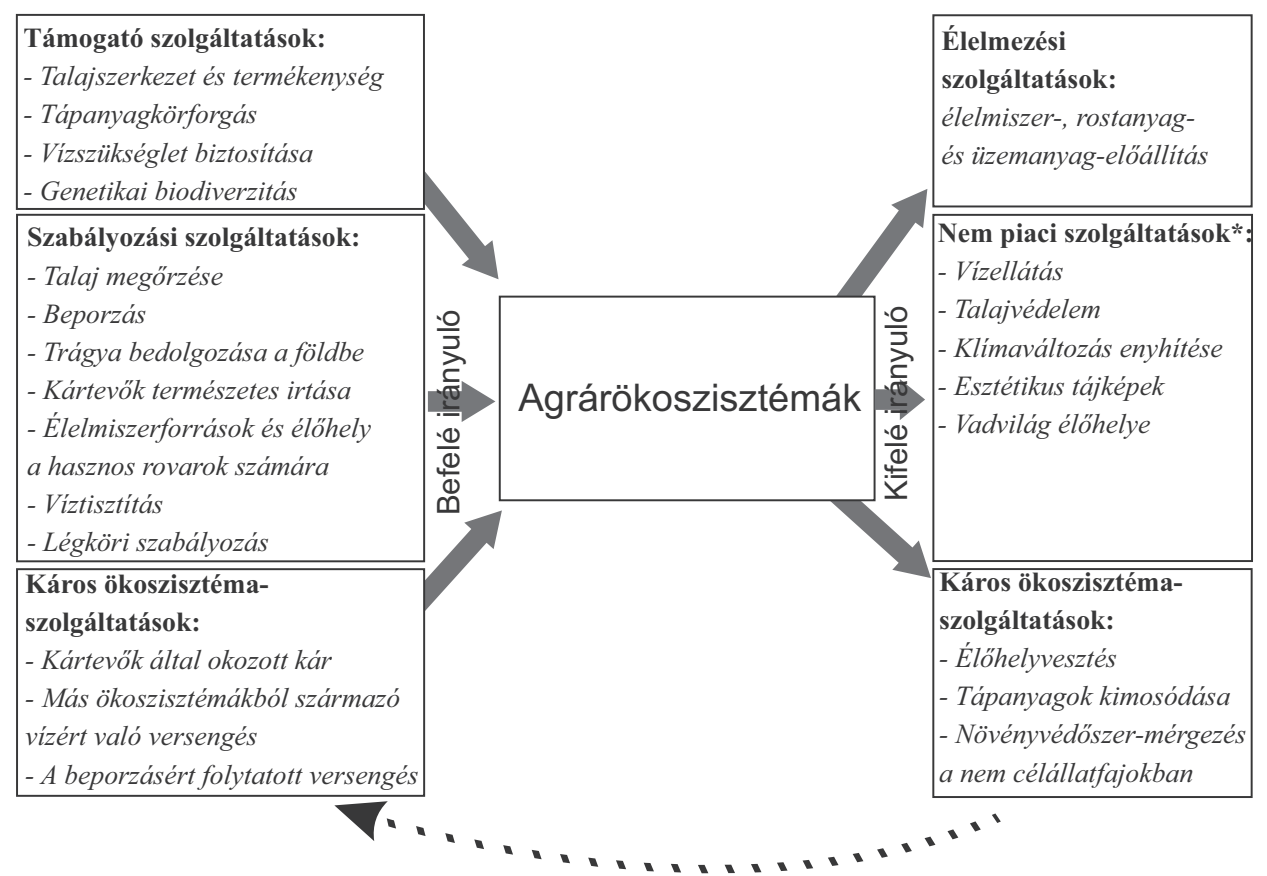

A mezőgazdaságból származó káros szolgáltatások visszacsatolási hatása a mezőgazdasági inputanyagokra (pl. a természetes ellenség élőhelyének eltüntetése kártevők robbanásszerü elszaporodását segítheti).

1. ábra. mezőgazdálkodás és az ökoszisztéma-szolgáltatások összefüggése (Zhang et al. 2007 alapján). *Ezek a szolgáltatások elsősorben extenzív vagy biotermelésben jelennek meg, az intenzív agrártájak inkább csökkentik e szolgáltatások jelenletét. 
melök megnyerését segítheti az együttmüködési bónusz pénzbeli ösztönzője egy adott tájegységi konfiguráció létrehozására vagy közös fenntartására. A vállalkozói ösztönzö a földtulajdonosokat célozza, hogy az ökoszisztémaszolgáltatáskímélö gazdálkodási rendszerekhez együtt hozzanak létre saját, tájegységi tervet (Stallman 2011). Ezzel összefüggésben az ökoszisztéma-szolgáltatások közötti átváltások (Kovács et al. 2015) a gazdálkodók szemszögéből leginkább úgy jelentkeznek, hogy milyen jellegü előnyt biztosítanak a gazdálkodóknak: magasabb hozamból adódó magánhasznot vagy a társadalom megbecsülését a közhasznú tájfenntartásért. A mezőgazdasági termelők ökoszisztéma-szolgáltatásokról alkotott elképzeléseiről szóló szakirodalom meglehetősen korlátozott, így a kutatás számára időszerű feladat a mezőgazdasági termelők ökoszisztéma-szolgáltatásokra vonatkozó percepcióinak részletes feltárása (Smith \& Sullivan 2014).

\section{Módszerek}

A QUESSA [Quantification of Ecological Services for Sustainable Agriculture - Ökológiai szolgáltatások számszerüsítése a fenntartható mezőgazdaságért] kutatás fókuszában a mezőgazdasági tájak féltermészetes élőhelyei által biztosított hasznok, ökoszisztéma-szolgáltatások értékelése állt nyolc országban (Hollandia, Egyesült Királyság, Németország, Svájc, Észtország, Magyarország, Olaszország, Franciaország). Kutatási kérdésünk, hogy a gazdálkodó közösségek miként érzékelik ezen élőhelyeket, az általuk nyújtott ökoszisztéma-szolgáltatásokat (hasznokat, esetleg károkat). Korábbi kutatások szerint e féltermészetes élőhelyek ugyanis a gazdálkodással érintett tájegység integráns részei és a biodiverzitás fontos forrásai, amelyeket az EU agrár-környezetvédelmi rendszerei is támogatnak (Holland et al. 2016). A féltermészetes élöhelyeken kulcsfontosságú ökoszisztéma-szolgáltatást nyújtó élőlények (pl. gerinctelenek) élnek. Ezek megléte fontos magyarázó változó a mezőgazdasági termelők biodiverzitás-megőrzés iránti hajlandóságában is. Emiatt a féltermészetes élőhelyek fenntartása döntő szerepet játszik abban is, hogy mezőgazdasági termelöket a környezetgazdálkodásban érdekeltté, elkötelezetté lehessen tenni (Wilson \& Howarth 2002).

A terepkutatások során nem pénzbeli ökoszisztéma-szolgáltatás értékelési módszertan segítségével ismertük meg a gazdálkodók percepcióit, véleményét a féltermészetes élőhelyek előnyeiről, ökoszisztéma-szolgáltatásairól. Társadalomtudományi kutatási módszerek széles spektruma áll rendelkezésre az ökoszisztéma-szolgáltatások nem pénzbeli értékelésére: kvantitatív és szemikvantitatív társadalomtudományi módszerek és kvalitatív, az érintettek részvételén alapuló módszerek egyaránt használhatók és kombinálhatók döntéselemzési eszközökkel 
(Kelemen et al. 2014, Santos-Martín et al. 2017). A QUESSA projektben társadalomtudományi kutatási tapasztalattal nem rendelkező ökológusok részére fejlesztettünk ki könnyen használható kvalitatív értékelési eljárásokat. Ezen interjúk és fókuszcsoportos megbeszélések fő célja a természetvédelmi, növényvédelmi szándékkal végzett terepi felvételezések társadalmi jelentősségének és a mezőgazdasági termelők ökológiai kutatással szembeni elköteleződésének növelése volt. Korábbi kutatások ugyanis egyértelmúen mutatták, hogy a helyi mezőgazdasági termelők nem mindig vannak tudatában az ökoszisztéma-szolgáltatásoknak, a természetes élőhelyek értékének, illetve a tudományos eredményeket nem tekintik sajátjuknak, olykor nem is fogadják el relevánsnak (például Buijs et al. 2008).

A QUESSA projekt agroökoszisztémáival kapcsolatos fókuszcsoportos kutatást az 1. táblázat tartalmazza.

A kutatási kérdéseket a QUESSA projekt a BIOBIO FP7 projektre építve alakította ki, amelyben a konzorciumi partnerek korábban együttmüködtek (Kelemen et al. 2013). A munkahipotézisek az ökoszisztéma-szolgáltatások fogalmára (H1, $\mathrm{H} 2, \mathrm{H} 3)$, illetve az ökoszisztéma-szolgáltatások értékeire (H4, H5) vonatkoztak:

- H1 a kutatók és a gazdálkodók ökoszisztéma-szolgáltatás értlemezése közötti különbségről: A gazdálkodók ökoszisztéma-szolgáltatás értelmezése és az ökoszisztéma-szolgáltatás tudományos definíciója között nincsen számottevő különbség.

- $\quad$ H2 a bio- és a konvencionális gazdálkodási rendszerek közötti különbségröl: A biogazdálkodók és a természetközeli gazdálkodást folytatók komplexebb képet alkotnak az ökoszisztéma-szolgáltatásokról, mint a konvencionális termelésben részt vevő termelők.

- H3 a közös megértésről: A fókuszcsoportos megbeszélések során lehetőség nyílik a helyi gazdálkodók és a terepi kutatók számára egyaránt elfogadható közös elképzelés kialakítására az ökoszisztéma-szolgáltatásokról.

- $\quad$ H4 a gazdasági kontra nem gazdasági értékek megbecsüléséről: A konvencionális gazdálkodók jobban elismerik az ökoszisztéma-szolgáltatások azon előnyeit, amelyek közvetlenül a termeléshez köthetők (közvetlen gazdasági hasznot jelentenek), míg a bio és természetközeli gazdálkodást folytató termelők jobban elismerik az ökoszisztéma-szolgáltatások közvetett (nem gazdasági) elönyeit.

- $\quad$ H5 az ökoszisztéma-szolgáltatások értékeinek percepciójáról: Minél inkább a helyi közösséghez köthető az ökoszisztéma-szolgáltatások értékelése a résztvevők az ökoszisztéma-szolgáltatások annál több hasznát képesek érzékelni.

Az adatgyüjtés fókuszcsoportos megbeszéléseken zajlott, és kiegészítő információforrásként előzetes adatokat gyüjtöttünk termelőkkel folytatott interjúkból 
1. táblázat. Az esettanulmányok agroökológiai környezete és a fókuszcsoportok szervezésének jellemzői. ( $\mathrm{PC}=$ kártevő gyérítés (pest control), $\mathrm{PO}=$ beporzás (pollination))

\begin{tabular}{|c|c|c|c|c|c|}
\hline Esettanulmány & $\begin{array}{l}\text { Agroklima- } \\
\text { tikus zóna; } \\
\text { Dátum; } \\
\text { Időtartam }\end{array}$ & $\begin{array}{l}\text { Növényi } \\
\text { kultúra; }\end{array}$ & Résztvevők & $\begin{array}{l}\text { Közösség érzete, } \\
\text { áramlás érzékelése }\end{array}$ & $\begin{array}{l}\text { Közös és meg- } \\
\text { különböztető̋ } \\
\text { tulajdonságok }\end{array}$ \\
\hline $\begin{array}{l}\text { FDEA-ART, } \\
\text { Svájc }\end{array}$ & $\begin{array}{l}\text { Atlanti; } \\
\text { 2014.03.17.; } \\
\text { 100 perc }\end{array}$ & $\begin{array}{l}\text { Olajrepce: } \\
\text { PC, PO }\end{array}$ & $\begin{array}{l}8 \text { professzionális } \\
\text { gyümölcster- } \\
\text { mesztő innovatív, } \\
\text { nyereségorientált } \\
\text { gondolkodással } \\
\text { - erösen intenzív } \\
\text { specialista gyü- } \\
\text { mölcstermesztötöl } \\
\text { a kisméretü, vegyes } \\
\text { gazdaságig }\end{array}$ & $\begin{array}{l}\text { A közösségérzet fi- } \\
\text { gyelemre méltó volt }\end{array}$ & $\begin{array}{c}\text { Közvetlen } \\
\text { interakciók } \\
\text { a résztvevök } \\
\text { között }\end{array}$ \\
\hline $\begin{array}{l}\text { GWCT, } \\
\text { Egyesült } \\
\text { Királyság }\end{array}$ & $\begin{array}{l}\text { Atlanti; } \\
\text { 2015. 01.21.; } \\
\text { 180 perc }\end{array}$ & $\begin{array}{l}\text { Búza: PC; } \\
\text { Olajrepce: } \\
\text { PO }\end{array}$ & $\begin{array}{l}4 \text { hagyományos } \\
\text { nagy gazdaság } \\
\text { (tulajdonos vagy } \\
\text { gazdaságvezető) }\end{array}$ & $\begin{array}{c}\text { Tájékozott és } \\
\text { nyugodt, nagyon szí- } \\
\text { vélyes és barátságos, } \\
\text { A termelők a befeje- } \\
\text { zésig elkötelezettek } \\
\text { maradtak }\end{array}$ & $\begin{array}{c}\text { Teljes kép } \\
\text { arról, hogy a } \\
\text { mezőgazdasági } \\
\text { termelők mit } \\
\text { szerettek a } \\
\text { gazdaságaikban } \\
\text { és a tájegysége- } \\
\text { ikben }\end{array}$ \\
\hline $\begin{array}{l}\text { BXSCAGRO, } \\
\text { Franciaország }\end{array}$ & $\begin{array}{l}\text { Mediterrán; } \\
\text { 2015.06.24.; } \\
\text { 150 perc }\end{array}$ & Szőlő: PC & 5 szőlőtermesztő & $\begin{array}{l}\text { A résztvevők széles } \\
\text { látókörủek voltak, } \\
\text { készen álltak meg- } \\
\text { hallgatni egymást } \\
\text { A közösségérzet } \\
\text { nagyon jól megfi- } \\
\text { gyelhető volt azokon } \\
\text { a kapcsolatokon } \\
\text { keresztül, hogy } \\
\text { hasonló problémák- } \\
\text { kal hogyan birkóztak } \\
\text { meg }\end{array}$ & $\begin{array}{c}\text { Sok megbeszé- } \\
\text { lés és közvetlen } \\
\text { interakció, amit } \\
\text { a tudományos } \\
\text { kísérletek } \\
\text { eredményei } \\
\text { indítottak be }\end{array}$ \\
\hline $\begin{array}{l}\text { DLO, } \\
\text { Hollandia }\end{array}$ & $\begin{array}{c}\text { Atlanti; } \\
\text { 2015.03.23.; } \\
\text { 120 perc }\end{array}$ & $\begin{array}{l}\text { Körte: PC, } \\
\text { PO }\end{array}$ & $\begin{array}{c}6 \text { gyümölcster- } \\
\text { mesztő }\end{array}$ & $\begin{array}{c}\text { Proaktív, széles } \\
\text { látókörü; A közös- } \\
\text { ségérzet természe- } \\
\text { tesen jelent meg a } \\
\text { gyümölcsösben tett } \\
\text { séta alatt }\end{array}$ & $\begin{array}{c}\text { Egy vizsgálati } \\
\text { csoport tagjai, } \\
\text { akik jól infor- } \\
\text { máltak voltak a } \\
\text { körtelevél-bolha } \\
\text { ügyében }\end{array}$ \\
\hline $\begin{array}{l}\text { EULS, } \\
\text { Észtország }\end{array}$ & $\begin{array}{l}\text { Észak keleti; } \\
2014.02 .07 . ; \\
100 \text { perc }\end{array}$ & $\begin{array}{l}\text { Olajrepce: } \\
\text { PC, PO }\end{array}$ & $\begin{array}{l}8 \text { hagyományos } \\
(160-1800 \text { ha) }\end{array}$ & $\begin{array}{l}\text { Együttmüködő és } \\
\text { kedélyes; Minden- } \\
\text { ki készségesen és } \\
\text { aktívan vett részt }\end{array}$ & $\begin{array}{l}\text { Senki sem } \\
\text { érezte úgy, hogy } \\
\text { kihagyják a } \\
\text { beszélgetésből; } \\
\text { A fö aggályuk } \\
\text { az volt, hogy } \\
\text { hogyan szár- } \\
\text { mazhat előnyük } \\
\text { a Quessából }\end{array}$ \\
\hline
\end{tabular}


1. táblázat (folytatás). Az esettanulmányok agroökológiai környezete és a fókuszcsoportok szervezésének jellemzői. ( $\mathrm{PC}=$ kártevő gyérítés (pest control), $\mathrm{PO}=$ beporzás (pollination))

\begin{tabular}{|c|c|c|c|c|c|}
\hline Esettanulmány & $\begin{array}{l}\text { Agroklima- } \\
\text { tikus zóna; } \\
\text { Dátum; } \\
\text { Időtartam }\end{array}$ & $\begin{array}{l}\text { Növényi } \\
\text { kultúra; }\end{array}$ & Résztvevők & $\begin{array}{l}\text { Közösség érzete, } \\
\text { áramlás érzékelése }\end{array}$ & $\begin{array}{l}\text { Közös és meg- } \\
\text { különböztető } \\
\text { tulajdonságok }\end{array}$ \\
\hline $\begin{array}{l}\text { UKL, Német- } \\
\text { ország }\end{array}$ & $\begin{array}{l}\text { Atlanti; } \\
\text { 2014.03.14.; } \\
\text { 100 perc }\end{array}$ & $\begin{array}{c}\text { Úritök: PO, } \\
\text { PC }\end{array}$ & $\begin{array}{c}6 \text { mezőgazdasági } \\
\text { termelö + } 1 \text { feleség } \\
\text { bio (kezdetben } \\
2, \text { később 4), } 3 \\
\text { hagyományos }\end{array}$ & $\begin{array}{l}\text { Együttmüködő, néha } \\
\text { lassú, néha szétforgá- } \\
\text { csolódó megbeszé- } \\
\text { lés, de összességében } \\
\text { jól követhető }\end{array}$ & $\begin{array}{l}\text { Mindenki prob- } \\
\text { lémának látta } \\
\text { a turizmust, és } \\
\text { valamennyien } \\
\text { vitatták a félter- } \\
\text { mészetes élőhe- } \\
\text { lyeken történő } \\
\text { gazdálkodást }\end{array}$ \\
\hline $\begin{array}{l}\text { SZIE, Magyar- } \\
\text { ország }\end{array}$ & $\begin{array}{l}\text { Közép } \\
\text { Európai; } \\
\text { 2014.03.04.; } \\
100 \text { perc }\end{array}$ & $\begin{array}{c}\text { Búza: PC, } \\
\text { Napraforgó: } \\
\text { PO }\end{array}$ & $\begin{array}{l}4 \text { mezögazdasági } \\
\text { termelő (kis lépték, } \\
\text { együttmüködö) }\end{array}$ & $\begin{array}{l}\text { Gyümölcsöző és } \\
\text { intenzív, élénk } \\
\text { megbeszélés; Nem } \\
\text { volt nagy kont- } \\
\text { raszt a termelők fö } \\
\text { elgondolásaiban és } \\
\text { megközelítéseiben }\end{array}$ & $\begin{array}{l}\text { A régi gazdasá- } \\
\text { gok és tanyák } \\
\text { kérdése igen } \\
\text { erőteljesnek } \\
\text { bizonyult, és } \\
\text { emlékek és } \\
\text { érzelmek vég } \\
\text { nélküli áramlá- } \\
\text { sát idézte meg }\end{array}$ \\
\hline $\begin{array}{c}\text { SSSA, } \\
\text { Olaszország } \\
\text { (napraforgó) }\end{array}$ & $\begin{array}{l}\text { Mediterrán; } \\
\text { 2015.01.04.; } \\
90 \text { perc }\end{array}$ & $\begin{array}{c}\text { Napraforgó: } \\
\text { PO }\end{array}$ & $\begin{array}{c}10 \text { napraforgó-ter- } \\
\text { mesztő }\end{array}$ & $\begin{array}{l}\text { A mezőgazdasági } \\
\text { termelök viszonylag } \\
\text { hallgatagok voltak, } \\
\text { és az uralkodó véle- } \\
\text { ményekre figyeltek }\end{array}$ & $\begin{array}{c}\text { Egymás között } \\
\text { sokat beszéltek } \\
\text { a gazdálko- } \\
\text { dással és a } \\
\text { szabályozások- } \\
\text { kal kapcsolatos } \\
\text { problémák- } \\
\text { ról; Kevés } \\
\text { érdeklödés az } \\
\text { ökoszisztéma- } \\
\text { szolgáltatások } \\
\text { vagy féltermé- } \\
\text { szetes élőhelyek } \\
\text { iránt }\end{array}$ \\
\hline $\begin{array}{l}\text { SSSA, Olasz- } \\
\text { ország (olíva) }\end{array}$ & $\begin{array}{l}\text { Mediterrán; } \\
\text { 2015.04.15.; } \\
90 \text { perc }\end{array}$ & Olíva: PC & $\begin{array}{l}7 \text { olajfa nevelé- } \\
\text { sével foglalkozó } \\
\text { termelő }\end{array}$ & $\begin{array}{c}\text { A megbeszélések } \\
\text { segítettek kibeszélni } \\
\text { a jogi szabályozások- } \\
\text { kal, nemzeti és helyi } \\
\text { szintű politikusaikkal } \\
\text { kapcsolatos sérel- } \\
\text { meiket }\end{array}$ & $\begin{array}{c}\text { Remény arra } \\
\text { vonatkozóan, } \\
\text { hogy a Quessa } \\
\text { befolyásolja a } \\
\text { helyi döntésho- } \\
\text { zókat }\end{array}$ \\
\hline
\end{tabular}


arra vonatkozóan, hogyan értékelik a tájegységet, a természet értékeit és a gazdálkodási rendszert. Kutatásunk feltáró jellegü volt és az ökológus kutatókat arra invitálták, hogy alakítsanak ki folyamatos terepi kapcsolatot a mezőgazdasági termelőkkel. A részt vevő kutatók számára 2013 novemberében tartottunk módszertani tréninget, amely a féltermészetes élőhelyek és az agroökoszisztémák nempénzbeli értékeléséhez biztosította az elméleti és gyakorlati alapokat. A képzési modulok és módszertani útmutatók megtalálhatók a http1 honlapon.

Az adatgyüjtés során csak azokat a termelőket hívtuk fókuszcsoportos beszélgetésre, akik a vizsgált agrár-ökoszisztémákban gazdálkodnak, a kutatáshoz a terepi felvételezés során is kapcsolódnak és az előzetes interjúk alapján az ökoszisztéma-szolgáltatásokra vonatkozó közvetlen tapasztalattal rendelkeznek. Az átlagos gazdálkodóknál tehát könnyebben kapcsolatba tudják hozni az ökoszisztéma-szolgáltatásokat a helyes mezőgazdálkodási gyakorlattal. A feltáró egyéni interjúk a helyi gazdálkodási gyakorlatok és a tájváltozások történetéről szóltak, míg a fókuszcsoportok során a gazdálkodók a féltermészetes élőhelyek előnyeit fényképek segítségével csoportosan értékelték. A csoportok moderálását a terepi kutatásban részt vevő és a csoportdinamikai folyamatokban jártas ökológus kutatók látták el.

A fókuszcsoportok vezérfonala a következő volt:

- Bevezetés: megkértük a résztvevőket, hogy röviden mutassák be magukat nevükkel együtt, és meséljenek pár szót a gazdaságukról.

- Bemelegítés: a termelőket elöször a helyi tájra vonatkozó személyes benyomásaikról kérdeztük, ami miatt szeretnek az adott helyen gazdálkodni és élni.

- Vizuális gyakorlat - gondolattérképezés (Soini 2011): a feltáró interjúk alapján az ökológus kutatók kiválasztották a legfontosabb 5 ökoszisztéma-szolgáltatást, majd a csoportbeszélgetéseken a termelők logikai kapcsolatokat vontak az egymáshoz kapcsolódó fogalmak között.

- Moderált megbeszélés: Ezt követően arra kértük őket, hogy kapcsolják össze e szavakat és a fogalmakat az ökoszisztéma-szolgáltatásokról az asztalon lévő fényképekkel. Ezután számos kérdés következett: Milyen körülmények között lehetséges ezen ökoszisztéma-szolgáltatásokat hosszú távon fenntartani? Hogyan függenek ezek az ökoszisztéma-szolgáltatások egymástól? Hogyan járulnak hozzá ezek az ökoszisztéma-szolgáltatások a helyi közösség jólétéhez? Melyek a pozitív és negatív hatásaik? Végezetül a mezőgazdasági termelöket megkérdeztük a féltermészetes élőhelyek értékéről.

- Zárás: A termelőket a záró gondolataikról kérdeztük, és megköszöntük, hogy megosztották a véleményüket a kutatókkal.

Adatelemzésre kvalitatív tartalomelemzési megközelítést választottunk (Kohlbacher 2006, Elo \& Kyngäs 2008), amelynek során az ökoszisztéma-szol- 
gáltatásokról szóló percepciókat deduktív módon, előre meghatározott kódkategóriákkal kódoltuk és hasonlítottuk össze (Patton 2002, illetve 2. függelék az online függelékben $[\mathrm{OF}])$. A deduktív elemzés arra a gondolatra épít, hogy az elméleti irodalom és a korábbi kutatási gyakorlatok alapján kialakított általános mintázat alapján ragadhatók meg az egyedi esetek (Mayring 2000). Ezért a fókuszcsoportok átirataiban előre kialakított kódok alapján zajlott a kódolás, ugyanakkor a kutatók új, a korábbi kódokkal nem lefedett kategóriákat is meghatározhattak. Az elemzés során a részt vevő kutatók egymástól is segítséget kértek, megosztották az ötleteiket és folyamatosan javították az eljárásaikat. A kódok kontextusbeli jellemzőit az online függelék [OF] 2. függelékében táblázatos formában közöljük.

Amikor a kódolást befejezték, a kutatókat megkértük, hogy töltsék fel a kódolási táblázatot kontextusbeli és tipikus attitüdöket érintő szövegrészletekkel, a fókuszcsoportokban zajlott beszélgetések átiratainak kivonatolásával. A kódolás ezen eredményei és a fogalomtérképezési gyakorlat adta az elemzés alapvető információforrását. A fókuszcsoportos kutatás eredményeink általánosíthatóságára vonatkozóan elmondhatjuk, hogy az a nyolc Quessa agrárökoszisztémára érvényes (1. táblázat). A kis mintaméret nem tett lehetővé a fókuszcsoportok gazdaságtípus, gazdálkodási rendszer, gazdaságméret, valamint a mezőgazdasági termelők életkora, neme és képzési szintje szerinti homogenizálást. A kutatás megbízhatósága javítható a mintaméret kiterjesztésével és az egyes agrárökoszisztémákban többféle gazdálkodási rendszert vizsgáló fókuszcsoportok megszervezésével.

A vizsgálatok változatos szocio-ökonómiai és kulturális kontextusának megfelelöen a mezőgazdasági termelők sokféle témát hoztak a fókuszcsoportos beszélgetésekbe. A fókuszcsoportok jól tükrözik a mezőgazdasági termelők Európán belüli heterogenitását és helyi specifikumait:

- Az Egyesült Királyságban zajló fókuszcsoport résztvevői valamennyien hagyományos módon gazdálkodtak, gazdaságméretük körülbelül 200-2000 hektár (500 és 5000 angol hold) között változott. Egy résztvevőnek a tulajdonában állt a földterület, amelyen gazdálkodott, a többi résztvevő a terület bérlője volt, és mindannyian környezetgazdálkodási programban vettek részt.

- Magyarországon a fókuszcsoport résztvevői konvencionális módon gazdálkodtak, és csak egy gazdaság volt biogazdaság. Két mezőgazdasági termelő kis léptékben (14 ha) gazdálkodott, és két másik okleveles mezőgazdász a helyi mezőgazdasági szövetkezetnél dolgozott (5000 és 20000 hektár), valamint saját gazdaságukat is vezették otthon. A termesztett növényi kultúrák jellemzően a kukorica, az őszi búza, a napraforgó, az árpa és a repce voltak. Egy gazdaság jóval változatosabb növényi kultúrákat is termesztett: köles, úritök, borsó, lucerna, tönkölybúza stb. 
- Hollandiában hat, konvencionális gyümölcstermesztő vett részt a megbeszélésen, valamennyien tagjai egy körtelevélbolhával foglalkozó vizsgálati csoportnak, valamennyien innovatív, nyereségorientált gondolkodásúak. Voltak köztük intenzív gyümölcstermelők és kisméretü, vegyes gazdaságok is, emiatt számottevő változatosságot mutattak az ökoszisztéma-szolgáltatások iránti attitüdjükben.

- Az észtországi esettanulmány fókuszcsoportjának résztvevője nyolc, hagyományos növényi kultúra termesztője volt (gabonafélék, olajrepce, lóhere, búza, árpa, zab, borsó, legelők) 160 és 1800 ha (átlagosan 826 ha) gazdaságmérettel és az adott vidékhez füződő erős kapcsolattal. Egyikük a konvencionális termesztés mellett bio- és alacsony inputtal dolgozó gazdálkodást is folytatott.

- Olaszországban a Monte Pisana-i (Pisa) olajfaligetes esettanulmányt az olívaolaj-sajtoló-üzem hét tulajdonosával folytatták. A résztvevők tehát professzionális mezőgazdasági termelők voltak; egyikük egy faiskola tulajdonosa és 1250 olajfa gondozója, a többiek 400-1200 fát gondoztak, míg egyikük 30 éve hobbiból folytat mezőgazdasági termelést 164 olajfával.

- Olaszországban a napraforgós fókuszcsoportot Pisa szerződéses munkavállalói társaságának 10 tagjával szervezték meg, akik saját földjeiken is gazdálkodnak. Egyikük müvelés nélküli direktvetéses gazdálkodást folytat, és van egy bemutató gazdasága a talaj szervesanyag megőrzéséről.

- Franciaországban a fókuszcsoportot 5 bortermelővel (magánpincészetek tulajdonosaival és egyikük egy borkészítő szövetkezeti taggal) folytatták le, és valamennyien növényvédelmi kísérletekben vettek részt. Hárman közülük bioszőlőben gazdálkodtak, míg a másik 2 résztvevő alacsony inputtal dolgozó rendszerekben volt érintett.

- A svájci esettanulmány fókuszcsoportjába nyolc mezőgazdasági termelőt hívtak meg körülbelül 10 kilométeres körzetböl; valamennyien agrár-környezetvédelmi gazdálkodásban vettek részt. Közösségi érzésük figyelemre méltó volt, és élvezték a közvetlen interakció lehetőségét.

- Németországban a fókuszcsoportot 7 helyi mezőgazdasági termelővel (6 mezőgazdasági termelővel és az egyik termelö feleségével) szervezték meg, akik közül négyen biotermeléssel foglalkoztak. Mindenki gazdálkodó családból érkezett, és valamennyien ott is születtek, ahol gazdálkodási tevékenységet végeztek.

Ahogyan az 1. táblázat is mutatja, a fókuszcsoportok rendszerint az elvárt résztvevők minimális számát vonzották. Az összejövetelek átlagos hossza 90 és 180 perc között változott, az átlag 120 perc volt, ami fókuszcsoportok esetén a standard időtartam. Rendszerint a vizuális gyakorlat és az ökoszisztéma-szolgáltatá- 
sok fogalmi összekapcsolása vett el több időt. A moderálás és a csoportdinamika vonatkozásában csak kis különbségekkel találkoztunk, és a moderátorok sikeresnek érezték munkájukat a beszélgetések fókuszának megőrzésében. A résztvevőket érezhetően megmozgatta a téma, ami a sikeres csoportmunkához szükséges összhang megteremtésére elég is volt. A fó kihívást az jelentette, hogy a részt vevő termelők életükben e beszélgetésen találkoztak először a féltermészetes élőhelyekkel és az ott előforduló ökoszisztéma-szolgáltatásokkal. A francia és az olasz esetben megküzdöttek a csoportos megbeszéléshez szükséges összhang megteremtésével, de ettől elkivéve a résztvevők kifejezetten jól érezték magukat. Összességében a csoportbeszélgetések résztvevői e témák vonatkozásában nem sok vitával vagy nézeteltéréssel kerültek szembe. A csoportokban sikerült pozitívlégkört kialakítani, ahol a mezőgazdasági termelők gyakran megerősítették egymás érzéseit, véleményét, tudását. A termelők ugyancsak alig várták, hogy meghallgathassák a gazdaságaikban zajló ökológiai vizsgálatok eredményeit, és erről gyakran kérdezték a kutatókat. A moderátorok szerepét erősítette, hogy a termelők komoly érdeklődést mutattak e megbeszéléseke és a projekt kitüzött céljai iránt.

\section{Eredmények}

A gazdálkodók ökoszisztéma-szolgáltatás értelmezései

A nem pénzbeli értékelés elsődleges célja annak megértése volt, hogy hogyan gondolkodnak a mezőgazdasági termelők az ökoszisztéma-szolgáltatásokról; azaz, milyen jellegü attitüdök, érzelmek, érvek jelennek meg, amikor az ökoszisztéma-szolgáltatásokról beszélnek. A gondolattérképezés (mind-mapping) során az ökoszisztéma-szolgáltatásokat ábrázoló képeket a moderátor vagy a kutató mutatta be a termelőknek, majd a korábbi interjúk és szakértői értékelés során azonosított 5 ökoszisztéma-szolgáltatás közötti kapcsolatokat vitatták meg (2. táblázat).

A beszélgetések során a termelök gyakorlati szemléletmódja érvényesült: az ökoszisztéma-szolgáltatás fogalmát saját gazdálkodási gyakorlatukra vonatkoztatták és azokban magán- vagy közhasznok előállítását látták. Kezdetben nehézkesnek találták a „szolgáltatások” lefordítását, ezzel együtt is, az ökoszisztémaszolgáltatások közötti kapcsolatokról kialakított tudásszintjét átlagon felülinek értékelték a kutatás ökológus résztvevői. Az ökoszisztéma-szolgáltatás fogalmát a termelök rendszerint és legkönnyebben a termelés hozamokban mért és jól látható sikerén keresztül értelmezték. Gazdálkodásukat közvetlenül formálják az ökoszisztéma-szolgáltatások és jelentős hatással vannak a gazdálkodás sikerére is, emiatt a termelők szemében nem szükségszerủen hasznosak. Az ökoszisztémaszolgáltatás-kímélő gazdálkodási rendszerek szempontjából a termelők az 
elsődleges érintettek, akik a negatív következményekkel (vadkár, csapadék) is közvetlenül szembesülnek. A féltermészetes élőhelyek nyújtotta ökoszisztémaszolgáltatásokról (vízháztartás, tápanyag-körforgás) rengeteg személyes megfigyelést osztottak meg a kutatókkal. A gondolattérképezés fontos eredménye, hogy nincs olyan gazdálkodói közösség, amelyben nem a hozamok maximalizálása, vagyis az ökoszisztéma-szolgáltatások gazdasági, termelésorientált megközelítése lenne a középpontban. Váratlan eredmény ugyanakkor, hogy a hozamot nem a termék mennyiségével hozzák csak kapcsolatba, hanem a gazdálkodás és a termés általános minőségével, ami jelentősen függ a féltermészetes élőhelyek biztosította „láthatatlan”, szabályozó szolgáltatásoktól. A gondolattérképezős gyakorlat segített azt is felszínre hozni, hogy a termelök saját identitásuk meghatározásakor elsődlegesen a helyi környezetben, az adott tájegységben élő és dolgozó emberekként tekintenek egymásra és magukra, nem csupán professzionális gazdálkodókként (v.ö. Burton 2004). A gondolattérképezésből egyértelmüvé vált, hogy a gazdálkodásban szerzett személyes tapasztalatok alapján az ökoszisztéma-szolgáltatások témája jobbára frusztrált, irritált, elégedetlen, szkeptikus, gyanakvó, önáldozatot hozó vagy aggódó érzelmi attitüdöket vált ki e körben. Pozitív érzések (elégedettség, elismertség, nosztalgia, érdeklődés, kíváncsiság) jóformán csak a gazdálkodás sikerét jelző ökoszisztéma-szolgáltatásokhoz kapcsolódnak. Hasonlóan, amikor a gazdaságukon belüli ökoszisztéma-szolgáltatásokról beszélnek, a termelők előnyben részesítik a racionális/professzionális érveket. Nem racionális szempontokat akkor emelnek be, amikor általában a természetről vagy a tájegységről szólnak. Végül, szinte minden fókuszcsoportban volt olyan gazdálkodó, aki hangot adott a vidéki táj iránti szeretetének. Ez a kulturális ökoszisztéma-szolgáltatások jelenlétére utal, s arra, hogy a gazdálkodók számára a táj nem csupán instrumentális szempontból, a gazdasági értékek miatt fontos, hanem a kézzel nem fogható kulturális, társadalmi értékek miatt is.

\section{A gazdálkodók attitüdje}

Több fókuszcsoportban érzékelhető volt, hogy a gazdálkodók erős érzelmi kapcsolatban álltak a tájjal: nagyra értékelték biodiverzitását és esztétikumát, és tudatában voltak a féltermészetes élőhelyről származó hasznoknak és ezek sebezhetőségének. Általában jellemzőnek mondható, hogy a termelők pozitív attitüddel álltak az ökoszisztéma-szolgáltatások többségéhez, különösen a hozam és a beporzás kérdéséhez, továbbá a rekreáció, a táj, a biodiverzitás megőrzés, a tápanyag-kimosódás csökkentése, a talaj egészsége és termékenysége, a mikroklíma-szabályozás vonatkozásában is. Mindezek olyan ökoszisztéma-szolgáltatások, amelyek a termelői tapasztalatok alapján főként a féltermészetes élőhelyek jó állapotától függenek. Az ökoszisztéma-szolgáltatások negatív megítélés alá gyakran a növek- 
2. táblázat. A fókuszcsoportokon megbeszélt öt legfontosabb ökoszisztéma-szolgáltatás.

\begin{tabular}{|c|c|}
\hline Ország & Öt legfontosabb ökoszisztéma-szolgáltatás \\
\hline Egyesült Királyság & $\begin{array}{l}\text { Terméshozam } \\
\text { Beporzás } \\
\text { Vadvilág } \\
\text { Rekreáció } \\
\text { Funkcionális biodiverzitás }\end{array}$ \\
\hline Magyarország & $\begin{array}{l}\text { Élőhely a vadállomány számára } \\
\text { Beporzás } \\
\text { Víztároló kapacitás } \\
\text { Kulturális kapacitás } \\
\text { Tájképi esztétikum }\end{array}$ \\
\hline Észtország & $\begin{array}{l}\text { Talaj termékenysége } \\
\text { Szénmegkötés } \\
\text { Beporzás } \\
\text { Hozam } \\
\text { Víztisztítás és -szabályozás }\end{array}$ \\
\hline Németország & $\begin{array}{l}\text { Talaj termékenysége } \\
\text { Szél, szennyezőanyagok, hordalék elleni } \\
\text { védelem } \\
\text { Beporzás } \\
\text { Vízszabályozás } \\
\text { Kártevők irtása }\end{array}$ \\
\hline Olaszország, olíva & $\begin{array}{l}\text { Élelmiszer, } \\
\text { A biodiverzitás megőrzése, } \\
\text { Rekreáció, } \\
\text { Esztétikum } \\
\text { Erózió szabályozása }\end{array}$ \\
\hline Svájc & $\begin{array}{l}\text { Vízvisszatartás } \\
\text { Erózióval szembeni védelem } \\
\text { Hozamok } \\
\text { A talaj egészsége } \\
\text { A biodiverzitás megőrzése }\end{array}$ \\
\hline Franciaország & $\begin{array}{l}\text { Kártevők gyérítése } \\
\text { Esztétikai érték } \\
\text { A talaj funkcionálása } \\
\text { Hozamok } \\
\text { Vízvisszatartási kapacitás }\end{array}$ \\
\hline Hollandia & $\begin{array}{l}\text { A biodiverzitás megőrzése } \\
\text { Szél elleni védelem } \\
\text { Beporzás } \\
\text { Hozamok } \\
\text { Mikroklíma }\end{array}$ \\
\hline Olaszország, napraforgó & $\begin{array}{l}\text { Vízminőség védelme } \\
\text { A biodiverzitás megörzése } \\
\text { Rekreáció, } \\
\text { Esztétikum } \\
\text { Mikroklíma-szabályozás }\end{array}$ \\
\hline
\end{tabular}


vő költségektől való félelemből fakadóan esnek, például a kártevő gyérítés vagy a funkcionális biodiverzitás esetében ${ }^{1}$. Az attitűdök ambivalensek: rendszerint személyes érzésekre és etikai megfontolásokra építenek, viszont ezekkel disszonáns racionális gazdasági érveket használnak. Ennek eredményeként a gazdálkodói ideálok és a valós gazdálkodási követelmények konfliktusba kerülnek egymással.

A gazdálkodók által érzékelt elönyök

Az, hogy mi alkotja egy ökoszisztéma-szolgáltatás hasznát, erősen kontextusfüggö. Általánosságban, az ökoszisztéma-szolgáltatásokból származó közvetlen gazdasági haszon, megélhetésük fö forrása bizonyult a termelők számára a legfontosabbnak. Ugyanakkor a túlélés érdekében kénytelenek kompromisszumot kötni az ökoszisztéma-szolgáltatás-kímélö gazdálkodás és a gazdasági életképesség, jövedelmezőség között. A termelők gyakran érzékeltették, hogy gazdálkodói identitásukban a helyi termelői és a helyi lakos elemei elválnak, mert a gazdasági fenntarthatóság szembekerül más haszonélvezők által különböző szinteken realizált egyéb (esztétikai, etikai, ökológiai) hasznokkal. Emiatt gyakran $a$ körülmények áldozataként mutatják be magukat, és veszteségeikért is másokat hibáztatnak - többnyire a távolabbi érintetteket (politika, természetvédelem, turizmus, befektetők, EU, stb.). Több esetben a helyi gazdálkodói közösség, mint a legkiszolgáltatottabb érintett csoport, bünbakként viseli a nem mezögazdasági lakosság természetkárositásáért a felelösséget. Például amikor agrárterületen megvalósuló állami építési beruházások környezetkárosító hatását más agrárterületek természetvédelmi kezelésbe vételével kompenzálják (Svájc), illetve amikor hasznos szolgáltatásokat nyújtó féltermészetes élőhelyek nem megfelelő hatósági kezelése a termelőknél hozamkiesésben csapódik le (Olaszország); vagy amikor egy önkormányzati kezdeményezésre kialakítanak biotóp hálózatot később egy új ipari park létesítésekor kompenzációként jelenítenek meg (Németország). A biodiverzitással foglalkozó szakpolitikákat érintő kritikájuk elsősorban arra irányult, hogy az csak az egyes gazdaságok szabályozása szintjén jelenik meg, holott az ökoszisztéma-szolgáltatások tájegységi és regionális léptékben jönnek létre (pl. növénykultúra változatossága) jönnek létre. A termelők szerint kevés elismerés és kompenzáció jár az ökoszisztémaszolgáltatás-kímélő gazdálkodás tájszintủ pozitív hatásaiért.

1 Megjegyzendő, hogy az újabb terminológiákban a funkcionális biodiverzitás nem ökoszisztéma szolgáltatás: az ökoszisztéma struktúrához tartozik a cascade modellben, az IPBES pedig a nature dobozba helyezi. 


\section{Értékelés}

A QuESSA (www.quessa.eu) EU7-s kutatási projekt az agrártájban jelen lévő féltermészetes élőhelyek szerepét vizsgálta az ökoszisztéma-szolgáltatások nyújtásában. Az ökoszisztéma-szolgáltatás értékelésben használatos módszertanok döntően szakértői módszereket alkalmaznak, a téma biológus kutatói vezetésével. A QUESSA projektben kifejezetten e szakértői módszerek transzdiszciplináris továbbfejlesztését tüztük ki célul: vagyis olyan társadalomtudományi kutatásmódszertani elemeket válogattunk össze, amelyek segítségével bármely gazdálkodói közösség és ökoszisztéma felmérést végzö ökológus képessé válik ökoszisztéma-szolgáltatások értékelésére.

Tanulmányunnk rámutatott, hogy valóban elővigyázatosságot igényel az ökoszisztéma-szolgáltatások tudományos fogalmának alkalmazása. Alkalmas lehet az előttünk álló összetett ökológiai szocio-ökonómiai és politikai kihívások megér(te)tésre, és kívánatos lenne, hogy a közpolitikai megoldások között nagyobb teret kapjon (Norgaard 2010). Kétségtelen, hogy a fogalom antropocentrikussága nem minden esetben segíti, hogy különböző szemszögből, alternatív megközelítésekkel láthassuk a világot (Silvertown 2015). Mivel megkerülhetetlen értelemzési keretté vált a transzdiszciplináris kutatásokban (Fisher et al. 2009, De Groot et al. 2010, Duru et al. 2015) és a szakpolitikai folyamatokban is, fontos, hogy az ökoszisztéma-szolgáltatások értékelése a gazdaságin túli értékekre és az értelmezési különbségekre érzékeny módon történjen, a résztvevők közös megértése mellett.

Öt munkahipotézist vizsgáltunk:

\section{A kutatók és gazdálkodók ökoszisztéma-szolgáltatás értelmezésének}

különbségéröl

Várakozásunknak megfelelően nem találtunk nagy különbséget a gazdálkodók által használatos és a tudományosan meghatározott elgondolásokban. Az országok között változatos válaszokat rögzítettünk a hipotézis nagyobb arányú elfogadásával és csak bizonyos mértékü elvetésével. A magyarországi esetben kifejezetten problémafókuszú megközelítés volt jellemző a gazdálkodói szemléletre: rendre a vadkár és a belvíz kérdései kerültek előtérbe. A svájci esetben a gazdák a munkájukat segítő szolgáltatásokat hangsúlyozták. Az észt gazdálkodók esetében pedig a szolgáltatások közti interakciók és átváltások is nyomatékosan megjelentek. 
2. A bio- és a konvencionális gazdálkodási rendszerek közötti különbségröl Alapfeltételezésünk szerint a környezetkímélő mezőgazdálkodást folytató gazdák összetettebb képet alkotnak az ökoszisztéma-szolgáltatásokról, mint a konvencionális mezőgazdaságban dolgozók. Mindezt a svájci gazdálkodók között végzett vizsgálat megerősítette, a német gazdák esete viszont cáfolta, hiszen a konvencionális gazdák is kiterjedt tudással rendelkeztek. Az észt és magyar gazdák közösségeiben nem volt jelentős e különbség, inkább életkor szerint mutatkoztak eltérések. E kérdés csak a minta növelésével és azonos agroökoszisztémákban dolgozó bio- és hagyományos termelőkkel végzett fókuszcsoportos vizsgálatokkal pontosítható.

\section{A közös megértésröl}

A gazdálkodói közösségek efféle közös mérlegelésre ösztönzése várakozásainknak megfelelően jó hatással volt a közös megértés kialakítására. A fókuszcsoportos vizsgálat megerősítette, hogy e megbeszélések során lehetőség nyílik a helyi gazdálkodók és a terepi kutatók számára egyaránt elfogadható közös elképzelés kialakítására az ökoszisztéma-szolgáltatásokról. A mezőgazdasági termelőkkel folytatott valamennyi megbeszélésen, az egyik olasz csoportot kivéve, lehetséges volt a közös álláspont kialakítása.

\section{A gazdasági kontra nem gazdasági értékek megbecsüléséröl}

A vizsgálat részben alátámasztja, hogy a konvencionális gazdálkodók jobban elismerik az ökoszisztéma-szolgáltatások azon elönyeit, amelyek közvetlenül a termeléshez köthetők (közvetlen gazdasági hasznot jelentenek), míg a bio és természetközeli gazdálkodást folytató termelők jobban elismerik az ökoszisztéma-szolgáltatások indirekt (nem gazdasági) előnyeit. Vizsgálatunk alapján tehát nem igazolható, hogy különbség lenne a konvencionális és környezetkímélő mezőgazdaságot preferáló gazdák között az ökoszisztéma-szolgáltatások pénzügyi és nem pénzügyi hasznainak értékelésében. Ugyanakkor az észt gazdák között az életkor szerint, a svájci gazdák között pedig a piacos és nem piacos termelést folytatók között jelentős eltérés mutatkozott. A hazai gazdálkodók között a saját földtulajdonnal rendelkező gazdálkodókra jellemzőbb volt a nem pénzügyi előnyök elfogadása. Összességében a német, a magyar és az észt gazdálkodók is jobban érzékelték az ökoszisztéma-szolgáltatások előnyeit. Releváns különbségek az idősebb és fiatalabb, a hobbi és professzionális mezőgazdasági termelök között jelentkeztek. 


\section{Az ökoszisztéma-szolgáltatások értékeinek percepciójáról}

A vizsgálat megerősítette, hogy minél inkább a helyi közösséghez köthető az ökoszisztéma-szolgáltatás értékelés szintje, a résztvevők az ökoszisztéma-szolgáltatások annál több hasznát képesek érzékelni. A helyi hasznokat jóval fontosabbnak találták.

Összességében, bár kvantifikálható eredményt nem vártunk és nem is kaptunk, az ökoszisztéma-szolgáltatásokról szóló tudásunk jelentősen gazdagítható a gazdálkodói csoportok szemléletének, értékeinek feltárásával. Amint számos szerző megállapította (Haines-Young \& Potschin 2010, Baveye et al. 2013, 2016), a fogalom alkalmas a gazdálkodók mindennapi, kézzelfogható gazdálkodási élményeinek, a magától értetődőnek gondolt, használati értéken túli (egészségügyi, társadalmi, esztétikai) értéktartományainak láthatóvá tételére. A kutatók jellemzően kész definíciókban és jól megragadható különbségekben gondolkodnak, míg a termelők a saját életvilágukra, sikereikre, éleményeikre vonatkoztatva közelítik meg az ökoszisztéma-szolgáltatásokat. Jelentős különbségek mutathatók ki a gazdálkodók értelmezésein belül is az ökoszisztéma-szolgáltatások értékelésében és ezek nem feltétlenül ragadhatók meg az ökoszisztéma-szolgáltatások által nyújtott közvetlen hasznokon keresztül. További kutatásra volna szükség annak érdekében, hogy e megállapítások hatókörét szisztematikusan szélesíteni lehessen az öko-agrár-élelmiszer komplex rendszerre, a mezőgazdaság és az ökoszisztéma-szolgáltatások kölcsönhatásainak társadalmi, környezeti, gazdasági és egészségügyi vonatkozásaira (TEEB 2015). A szakpolitikák tervezéséhez továbbá kívánatos volna a mezőgazdasági termelők értékőrző világszemléletét és rövidtávú nyereségorientált érdekeit egyensúlyba hozni, valamint - amint például Goldman és munkatársai (2007) javasolták - tájegységi léptékben ösztönözni az ökoszisztémaszolgáltatás-kímélő gazdálkodási rendszereket. A gazdálkodók ugyanis pontosan érzékelik a Lant és munkatársai (2008) által leírt jelenséget, miszerint, gazdálkodási gyakorlataik számos „láthatatlan”, „meg nem fizetett” (támogató, szabályozó és kulturális) ökoszisztéma-szolgáltatás rovására tudják csak növelni az élelmezési ökoszisztéma-szolgáltatásokat.

Az ökoszisztéma-szolgáltatásokkal (mint közjószágokkal) kapcsolatos preferenciák vizsgálatára a gazdálkodói részvételen alapuló értékelési módszerünk alkalmasnak bizonyult. A közös tanulásra építő fókuszcsoportos vizsgálat olcsó és a döntéshozatali folyamatba jól beilleszthető, amennyiben a szakpolitika elfogadja és alkalmazza a társadalmi részvétellel meghozott döntéseket.

Köszönetnyilvánitás - A kutatás az Európai Unió 7. Kutatási-, technológiafejlesztési és demonstrációs keretprogramjában (FP7) valósult meg a 311879-es számú pályázat keretében. Köszönet illet minden kollégát, aki részt vett a QUESSA projekt esettanulmányainak kidolgozásában, név szerint Katja Jacot és Gisela Lüscher (FDEA-ART), Barbara Smith 
és John Holland (GWCT), Brice Giffard (BxScAgro), Karin Winkler és Herman Helsen (WU), Eve Veromann, Gabriella Kovács és Riina Kaasik (EULS), Sonja Pfister és Martin Entling (UKL), Daniele Antichi (UNIPI), Papp Komáromi Judit, Kiss József és Zalai Mihály (SZIE) valamint Camilla Moonen (SSSA). Köszönettel tartozunk továbbá a kutatásban részt vevő gazdálkodóknak.

\section{Irodalomjegyzék}

Baveye, P. C., Baveye, J. \& Gowdy, J. (2013): Monetary valuation of ecosystem services: it matters to get the timeline right. - Ecol. Econ. 95: 231-235. doi: http://dx.doi.org/10.1016/j. ecolecon.2013.09.009

Baveye, P. C., Baveye, J. \& Gowdy, J. (2016): Soil "Ecosystem" Services and Natural Capital: Critical Appraisal of Research on Uncertain Ground. - Front. Environ. Sci. 4: 41. doi: http://journal. frontiersin.org/article/10.3389/fenvs.2016.00041/full

Buijs, A., Fisher, A., Rink, D. \& Young, C. J. (2008): Looking beyond superficial knowledge gaps: Understanding public representations of biodiversity. - International Journal of Biodiversity Science and Management 4: 65-80. doi: http://dx.doi.org/10.3843/Biodiv.4.2:1

Burton, R. J. F. (2004): Seeing Through the 'Good Farmer's' Eyes: Towards Developing an Understanding of the Social Symbolic Value of 'Productivist' Behaviour. - Sociol. Ruralis 44: 195215. doi: http://dx.doi.org/10.1111/j.1467-9523.2004.00270.x

De Groot, R., Fisher, B., Christie, M., Aronson, J., Braat, L., Haines-Young, R., Gowdy, J., Killeen, T., Maltby, E., Neuville, A., Polasky, S., Portela, R. \& Ring, I. (2010): Integrating the ecological and economic dimensions in biodiversity and ecosystem service valuation. - Draft Chapter 1 of The Economics of Ecosystems and Biodiversity (TEEB) study.

De Schutter, O. \& Petrini, C. (2017): Time to put a Common Food Policy on the menu. - In Politico, Op-Ed. Febr 2, 2017. URL: http://www.politico.eu/pro/opinion-time-to-put-a-common-foodpolicy-on-the-menu/

Duru, M., Therond, O., Martin, G., Martin-Clouaire, R., Magne, M-A., Justes, E., Journet, W-P., Aubertot, J-N., Savary, S., Bergez., J-E. \& Sarthou, J-P. (2015): How to implement biodiversitybased agriculture to enhance ecosystem services: a review. - Agron. Sustain. Dev. 35: 1259 1281. doi: http://dx.doi.org/10.1007/s13593-015-0306-1

Elo, S. \& Kyngäs, H. (2008): The Qualitative Content Analysis Process. -J. Adv. Nurs. 62: 107-115. doi: http://dx.doi.org/10.1111/j.1365-2648.2007.04569.x

FAO (2016): Adapting agriculture to climate change. URL: www.fao.org/docrep/011/aj982e/ aj982e02.pdf

Fisher, B., Turner, R. K. \& Morling, P. (2009): Defining and classifying ecosystem services for decision making. - Ecol. Econ. 68: 643-653. doi: https://doi.org/10.1016/j.ecolecon.2008.09.014

Goldman, R. L., Thompson, B. H. \& Daily, G. C. (2007): Institutional incentives for managing the landscape: Inducing cooperation for the production of ecosystem services. - Ecol. Econ, 64: 333-343. doi: https://doi.org/10.1016/j.ecolecon.2007.01.012

Haines-Young, R. \& Potschin, M. (2010): The links between biodiversity, ecosystem services and human well-being. - In: Raffaelli, D. G. \& Frid, C. L. J. (eds.): Ecosystem Ecology: A New Synthesis. - British Ecological Society, Cambridge University Press, pp. 110-139.

Holland, J. M, Jeanneret, P. , Herzog, F., Moonen, A-C., Rossing, W., van der Werf, W., Kiss, J., van Helden, M., Paracchini, M. L., Cresswell, J., Pointereau, P., Heijne, B., Veromann, E., Antichi, D., Entling, M. \& Balázs, B. (2014): The QuESSA Project: Quantification of Ecological Services 
for sustainable agriculture. Landscape Management for Functional Biodiversity. - International Organisation for Biological Control/West Palaearctic Regional Section Bulletin 100: 55-58.

Holland, J. M., Bianchi, F. J. J. A., Entling, M. H., Moonen, A. C., Smith, B. M. \& Jeanneret, P. (2016): Structure, function and management of semi-natural habitats for conservation biological control: A review of European studies. - Pest. Manag. Sci. 72: 1638-1651. doi: http://dx.doi. org $/ 10.1002 /$ ps.4318

IPES (2017): Towards a Common Food Policy for the European Union. - A 3-year process of research, reflection and citizen engagement. URL: http://www.ipes-food.org/images/Reports/ CFP ConceptNote.pdf

Kelemen, E. (2011): Árak vagy érvek? Módszertani dilemmák a természet szolgáltatásainak értékelésében. - Kovász 3: 31-57.

Kelemen, E, Pataki, Gy., Balázs, B., Bela, Gy., Fabók, V., Kalóczkai, Á., Kohlheb, N., Kovács, E., Kovács Krasznai, E. \& Mertens, C. (2014): A nem pénzbeli értékelési módszerek kontextusfüggő alkalmazásának tapasztalatai. - In: Kelemen, E. \& Pataky, Gy. (szerk.): Ökoszisztéma szolgáltatások: A természet- és társadalomtudományok metszéspontjában. - Szent István Egyetem, Környezet- és Tájgazdálkodási Intézet; Environmental Social Science Research Group (ESSRG), Gödöllö; Budapest, pp. 56-75.

Kelemen, E. \& Pataki, Gy. (2014): Az ökoszisztéma szolgáltatások értékelésének elméleti megalapozása. - In: Kelemen, E. \& Pataki, Gy. (szerk.): Ökoszisztéma szolgáltatások: A természet- és társadalomtudományok metszéspontjában. - Gödöllö; Budapest: Szent István Egyetem, Környezet- és Tájgazdálkodási Intézet; Environmental Social Science Research Group (ESSRG), Gödöllö, Budapest, pp. 35-55.

Kelemen, E., Nguyen, G., Gomiero, T., Kovács, E., Choisis, J.-P., Choisis, N., Paoletti, M. G., Podmaniczky, L., Ryschawy, J., Sarthou, J.-P., Herzog, F., Dennis, P. \& Balázs, K. (2013): Farmers' perceptions of biodiversity: Lessons from a discourse-based valuation study. - Land Use Policy 35: 318-328. doi: http://doi.org/10.1016/j.landusepol.2013.06.005

Kohlbacher, F. (2006): The Use of Qualitative Content Analysis in Case Study Research. - Forum: Qualitative Social Research. 7(1) URL: http://www.qualitative-research.net/index.php/fqs/article/view/75/153

Kovács, E., Kelemen, E. \& Pataki, Gy. (2011): Ökoszisztéma szolgáltatások a tudományterületek és a szakpolitikák metszéspontjaiban. - Természetvédelmi Közlem. 17: 1-11.

Kovács, E., Kelemen, E., Kalóczkai, Á., Margóczi, K. Pataki, Gy., Gébert, J., Málovics, Gy., Bálint, B., Roboz, Á., Krasznai Kovács, E. \& Mihók., M. (2015): Understanding the links between ecosystem service trade-offs and conflicts in protected areas. - Ecosyst. Serv. 12: 117-127. doi: http://doi.org/10.1016/j.ecoser.2014.09.012

Kovács-Hostyánszki, A., Espíndola, A., Vanbergen, A. J., Settele, J., Kremen, C. \& Dicks, L. V. (2017): Ecological intensification to mitigate impacts of conventional intensive land use on pollinators and pollination. - Ecol. Lett. 20: 673-689. doi: http://dx.doi.org/10.1111/ele.12762

Kumar, M. \& Kumar, P. (2008): Valuation of the ecosystem services: A psycho-cultural perspective. - Ecol. Econ. 64: 808-819. doi: http://doi.org/10.1016/j.ecolecon.2007.05.008

Lant, C. L., Ruhl, J. B. \& Kraft, S. E. (2008): The tragedy of ecosystem services. - BioScience 58: 969-974. doi: http://doi.org/10.1641/B581010

Lele, S., Springate-Baginski, O., Lakerveld, R., Deb, D. \& Dash, P. (2013): Ecosystem services: origins, contributions, pitfalls, and alternatives. - Conservat. Soc. 11: 343-358. doi: http://doi. org/10.4103/0972-4923.125752

Lescourret, F., Magda, D., Richard, G., Adam-Blondon, A. F., Bardy, M., Baudry, J. \& MartinClouaire, R. (2015): A social-ecological approach to managing multiple agroecosystem services. - Curr. Opin. Sust. 14: 68-75. doi: https://doi.org/10.1016/j.cosust.2015.04.001 
Martínez-Alier, J. (2002): The environmentalism of the poor. A study of ecological conflicts and valuation. - Edward Elgar. Cheltenham, UK.

Martín-López, B., Iniesta-Arandia, I., García-Llorente, M., Palomo, I., et al. (2012): Uncovering ecosystem services bundles through social preferences: Experimental evidence from Spain. PLoS ONE 7: e38970. doi: http://doi.org/10.1371/journal.pone.0038970

Mayring, P. (2000): Qualitative Content Analysis. - Forum: Qualitative Social Research. 1(2). Art. 20. URL: doi: http://www.qualitative-research.net/index.php/fqs/article/view/1089/2385

MEA (2005): Ecosystems and Human Well-being: Synthesis. - Island Press, Washington, DC.

Nahlik, A. M., Kentula, M. E., Fennessy, M. S. \& Landers, D. H. (2012): Where is the consensus? A proposed foundation for moving ecosystem service concepts into practice. - Ecol. Econ. 77: 27-35. doi: http://doi.org/10.1016/j.ecolecon.2012.01.001

Norgaard, R. B. (2010): Ecosystem services: From eye-opening metaphor to complexity blinder. Ecol. Econ. 69: 1219-1227. doi: http://doi.org/10.1016/j.ecolecon.2009.11.009

O'Hara, S. U. (1996): Discursive ethics in ecosystems valuation and environmental policy. - Ecol. Econ. 16: 95-107. doi: http://doi.org/10.1016/0921-8009(95)00085-2

Pasqual, U., Balvanera, P., Díaz, S., Pataki, Gy., Roth, E., Stenseke, M., Watson, R. T., Dessane, E. B., Islar, M., Kelemen, E., Maris, V., Quaas, M., Subramanian, S. M., Wittmer, H., Adlan, A., Ahn, S., Al-Hafedh ,W. S., Amankwah, E., Asah, S.T., Berry, P., Bilgin, A., Breslow, S. J., Bullock, C., Cácere, D., Daly-Hassen H., Figuero,a E., Golden, C.D., Gómez-Baggethun, E., González Jiménez, D., Houdet, J., Keune, H., Kumar, R., Ma, K., May, P. H., Mead, A., O’Farrel, P., Pandit, R., Pengue, W., Pichis Madruga, R., Popa, F., Preston, S., Pacheco-Balanza, D., Saaroski, H., Strassburg, B. B., van den Belt, M., Verma, M., Wickson, F. \& Yagi, N. (2017): Valuing nature's contributions to people: the IPBES approach. - Curr. Opin. Sust. 26: 7-16. doi: http:// dx.doi.org/10.1016/j.cosust.2016.12.006

Pataki Gy. (szerk.) (2014): A gazdasági versenyképesség és az ökoszisztéma-szolgáltatások összefüggése a mezögazdálkodás példáján. - kézirat, ESSRG, Budapest, $111 \mathrm{p}$.

Patton, M. Q. (2002): Qualitative Research and Evaluation Methods. - Sage, London, 598 p.

Sandhu, H. \& Wratten, S. (2013): Ecosystem services in farmland and cities. Ecosystem services in agricultural and urban landscapes. - In: Wratten, S., Sandhu, H., Cullen, R. \& Costanza, R., (eds.): Ecosystem Services in Agricultural and Urban Landscapes. - Wiley-Blackwell. Oxford. pp. 1-15.

Santos-Martín, F., Kelemen, E., García-Llorente, M., Jacobs, S., Oteros-Rozas, E., Palomo, I., Barton, D. N., Hevia, V. \& Martín-López, B. (2017): Socio-cultural valuation approaches. - In: Burkhard, B., Maes, J. (eds.): Mapping ecosystem services. - Pensoft Publishers. URL: http:// ab.pensoft.net/article/12837/list/1/

Silvertown, J. (2015). Have ecosystem services been oversold? - Trends Ecol. Evol. 30: 641-648. doi: http://doi.org/10.1016/j.tree.2015.08.007

Smith, H. F. \& Sullivan, C.A. (2014): Ecosystem services within agricultural landscapes - Farmers' perceptions.-Ecol. Econ. 98: 72-80. doi: http://doi.org/10.1016/j.ecolecon.2013.12.008

Soini, K. (2001): Exploring human dimensions of multifunctional landscapes through mapping and map making. - Landscape Urban Plan. 67: 225-239. doi: http://doi.org/10.1016/S01692046(01)00206-7

Stallman, H. R. (2011): Ecosystem services in agriculture: Determining suitability for provision by collective management. - Ecol. Econ. 71: 131-139. doi: http://doi.org/10.1016/j. ecolecon.2011.08.016

Sutherland, L. A., Darnhofer, I., Wilson, G. \& Zagata, L. (eds.) (2014): Transition pathways towards sustainability in agriculture: case studies from Europe. - CABI. 
Swinton S. M., Lupi F., Robertson G. P., Hamilton S. K. (2007): Ecosystem services and agriculture: cultivating agricultural ecosystems for diverse benefits. - Ecol. Econ. 64: 245-252. doi: http:// doi.org/10.1016/j.ecolecon.2007.09.020

TEEB (2015) TEEB for Agriculture \& Food: an interim report, United Nations Environment Programme, Geneva, Switzerland. URL: www.teebweb.org/agriculture-and-food/

Wilson, M. A. \& Howarth, R. B. (2002): Discourse-based valuation of ecosystem services: establishing fair outcomes through group deliberation. - Ecol. Econ. 41: 431-443. doi: http://doi. org/10.1016/S0921-8009(02)00092-7

Zhang, W., Ricketts, T. H., Kremen, C., Carney, K. \& Swinton, S. M. (2007): Ecosystem services and dis-services to agriculture. - Ecol. Econ. 64: 253-260. doi: http://doi.org/10.1016/j. ecolecon.2007.02.024

\section{Internetes hivatkozások:}

http1: https://www.essrg.hu/en/quessa/ (letöltés: 2017. március)

\section{Függelék:}

A cikkhez tartozó Online Függelékek a folyóirat honlapján találhatóak.

Függelék 1: Léptékek és szereplők az ökoszisztémaszolgáltatás-kímélő mezőgazdálkodásban

Függelék 2: Ökoszisztéma-szolgáltatás kódkategóriák 


\title{
Ecosystem Services of Semi-Natural Habitats Through the Eyes of Farmers
}

\author{
Bálint Balázs ${ }^{1,2}$, Eszter Kelemen ${ }^{1}$, György Pataki ${ }^{1,3}$ and Györgyi \\ Bela $^{1,2}$ \\ ${ }^{1}$ Environmental Social Science Research Group (ESSRG), \\ H-1024 Budapest, Rómer Flóris u. 38, Hungary \\ ${ }^{2}$ Szent István University, Institute of Nature Conservation and Landscape Management, \\ H-2100 Gödöllö, Páter Károly u. 1, Hungary \\ ${ }^{3}$ Corvinus University of Budapest, \\ H-1093 Budapest, Fövám tér 8, Hungary \\ e-mail:balazs.balint@essrg.hu
}

Farmers as primary land users have the most power to interact with the land. Therefore, understanding farmers' perception of ecosystem services (or ESs) through farmers' eyes is of primary importance: their assessments of ESs and their ideas about the possibilities of maintenance will be crucial for land management decisions. This comparative analysis presents how farmers understand the benefits and non-monetary value of on-farm ESs provided by semi-natural habitats in main cropping systems (arable, orchard, vegetable and vines) across four European agro-climatic zones in 8 European countries (the UK, Germany, France, Netherlands, Italy, Switzerland, Estonia and Hungary). Farmers attitudes towards ESs are ambivalent: they usually build on personal feelings and ethical considerations and at the same time use rational economic arguments. Farmers appreciated ESs in multiple ways (e.g. enjoying aesthetics and sense of place, benefiting from ESs, etc.) and valued it against the harm caused by pests, diseases and weeds (an indication of their success as agriculturalists). Positive attitudes typically go for yield and associated ESs including pollination; whereas negative attitudes are recorded towards Functional Biodiversity. Farmers have their own personal and ethical considerations, but these become dissonant with economic rationale and capacities in maintaining the farm. As a result, farming ideals and the real-world requirements are often in conflict. We also uncovered that the concept of ESs is very well received in each local contexts of farming. The exercise also pointed to the limits of monetary valuation in ES valuation, as they restrict benefits to economics which are seemingly important for maintaining the farm enterprise but less as an ideal for agriculturalists. Farmers mention 'yields' as the most important as this is the main success criteria represented by the Common Agriculutral Policy towards farming - however, according to farmers, this becomes problematic as yields are not equal with the money gained in exchange.

Keywords: semi-natural habitat, ecosystem services, QUESSA FP7, agroecosystem, qualitative research, non-monetary valuation 